\title{
HUBUNGAN POLA ASUH ORANG TUA DENGAN PENYIMPANGAN MENTAL EMOSIONAL ANAK PRASEKOLAH USIA 4-5 TAHUN (Di TK Kartika Jaya Kecamatan Kademangan Kabupaten Blitar)
}

Soemarmi ${ }^{1}$, Susiani Endarwati ${ }^{2}$, Anis Nurohmah ${ }^{3}$ Akademi Kebidanan Dharma Husada Kediri

\begin{abstract}
ABSTRAK
Orang tua memiliki peranan yang sangat penting dalam upaya mendukung perkembangan emosional anak. Namun permasalahan sering kali muncul, manakala orang tua sering kurang tanggap.Tujuan penelitian ini adalah mengetahui hubungan pola asuh orang tua dengan penyimpangan mental emosional anak pra sekolah usia 4-5 tahun di TK Kartika Jaya.

Desain penelitian ini adalah metode analitik. Populasi dalam penelitian ini adalah semua orang tua yang mempunyai anak pra sekolah usia 4-5 tahun di TK Kartika Jaya sejumlah 32 orang dengan menggunakan total sampling. Variabel penelitian ini adalah variable independen pola asuh orang tua dan variable dependen adalah perkembangan emosional anak pra sekolah 4-5 tahun. Instrumen penelitian ini menggunakan kuesioner. Pengolahan data menggunakan editting, coding, scoring dan tabulating. Analisa data dengan chi square.

Hasil penelitian didapatkan sebagian besar responden menerapkan pola asuh authoritative yaitu sebanyak 29 responden (91\%). Dan perkembangan emosional yang sesuai yaitu 22 anak (69\%), perkembangan emosional yang meragukan 6 anak $(19 \%)$ dan perkembangan emosional yang mengalami penyimpangan sebanyak 4 anak (12\%). Dari perhitungan statistic menggunakan uji statistic chi square menunjukkan hasil $\chi^{2}$ hitung 10,421 dengan $\alpha 0,05$. Oleh karena itu $\chi^{2}$ hitung lebih besar dari $\chi^{2} \alpha \quad(10,421>5,991)$ maka dapat disimpulkan bahwa H0 ditolak dan $\mathrm{H} 1$ diterima. $\mathrm{H} 0$ ditolak dan $\mathrm{H} 1$ diterima yang artinya pola asuh orang tua berhubungan dengan penyimpangan mental emosional anak pra sekolah usia 4-5 tahun di TK Kartika JayaKecamatan Kademangan, Kabupaten Blitar.

Pola asuh yang diterapkan orang tua sangat erat hubungannya dengan penyimpangan emosional.
\end{abstract}

Kata Kunci :PolaAsuh Orang Tua, Penyimpangan Mental Emosional 


\section{PENDAHULUAN}

Anak merupakan individu yang berada dalam satu rentang perubahan perkembangan yang dimulai dari bayi hingga remaja. Masa anak merupakan masa pertumbuhan dan perkembangan yang dimulai dari bayi ( 0-1 tahun ), usia bermain ( $1-2,5$ tahun ), usia sekolah ( 5-11 tahun ) hingga remaja ( 11-18 tahun) (Hidayat,2005:6). Masa prasekolah merupakan masa yang tergolong rawan dalam pertumbuhandan perkembangan anak. Menurut Huxley (2002) menyatakan bahwa pola asuh merupakan cara dimana orang tua menyampaikan / menetapkan kepercayaan mereka tentang bagaimana menjadi orang tua yang baik atau buruk. Anak-anak diibaratkan sebagai tunas dari orang tua, karena mereka akan tumbuh dan mempunyai masa depan sendiri. Kehidupannya diwarnai situasi yang menyenangkan dan spontanitasAnakanak memang mempunyai kehidupan emosi dinamis. Emosi anak masih bersifat labil dan tidak menentu. Artinya perubahan kondisi emosi bersifat fluktuatif, drastis dan cepat. (Daryo, 2007:179-180)

Di Indonesia sendiri, secara garis besar analisis data Survey Kesehatan Rumah Tangga (SKRT) mengenai gejala gangguan mental emosional anak, menunjukkan adanya angka yang cukup tinggi, yaitu 259 per 1000 anak. Sementara studi morbiditas SKRT di Jawa dan Bali mendapatkan angka

\section{METODE}

Desain penelitian yang digunakan adalah analitik cross-sectional. Variabel penelitian ini adalah variabel independen pola asuh orang tua dan variable gejala gangguan mental emosional sebesar 99 per 1000 penduduk (Isfandari dan Suhardi, 1997).

Orang tua memiliki peranan yang sangat penting dalam upaya mendukung perkembangan anak, khususnya saat mereka berada pada tahapan usia dini. ( Daryo, 2007:206).

Bila penyimpangan mental emosi 14 terlambat diketahui maka intervensınya akan lebih sulit dan hal ini akan berpengaruh pada tumbuh kembang anak. Deteksi ini dilakukan oleh tenaga kesehatan. Deteksi dini penyimpangan mental emosional adalah kegiatan/pemeriksaan untuk menemukan gangguan secara dini adanya masalah emosional, autisme dan gangguan pemusatan perhatian dan hiperaktivitas pada anak, agar dapat segera dilakukan tindakan intervensi.

Berdasarkan studi pendahuluan yang dilakukan pada tanggal 14 April 2014 di TK Kartika Jaya Kecamatan Kademangan, Kabupaten Blitar, dari 10 orang yang mempunyai anak usia prasekolah 4-5 tahun telah diketahui bahwa $6(60 \%)$ orang menerapkan pola asuh authoritatif kepada anaknya. Dan anak yang mendapat pola asuh demokratis anak tidak malu dengan orang lain. Dan $2(20 \%)$ orang menerapkan pola asuh othotarian kepada anaknya. anak yg diasuh dengan pola asuh outhotarian lebih sering marah

perkembangan emosional anak pra sekolah 4-5 tahun. Populasi dalam penelitian ini adalah semua orang tua yang mempunyai anak pra sekolah usia 4-5 tahun di TK Kartika Jaya sejumlah 
32 orang dengan menggunakan total sampling. Instrumen penelitian ini menggunakan kuesioner. Penelitian dilaksanakan pada tanggal 8-9 Mei
2014 di TK Kartika Jaya Kecamatan Kademangan, Kabupaten Blitar, JawaTimur.Analisa data dengan menggunakan chi square.

\section{HASIL}

Tabel 1. Tabulasi silang pola asuh orang tua dengan Penyimpangan Mental Emosional Anak Pra sekolah usia 4-5 tahun TK Kartika Jaya Desa Kademangan Kecamatan Kademangan Kabupaten Blitar

\begin{tabular}{|c|c|c|c|c|c|c|c|c|}
\hline \multirow{2}{*}{$\begin{array}{l}\text { Penyimpangan Mental Emosional } \\
\qquad \text { Pola Asuh Ibu }\end{array}$} & \multicolumn{2}{|c|}{ Sesuai } & \multicolumn{2}{|c|}{ Meragukan } & \multicolumn{2}{|c|}{$\begin{array}{c}\text { Penyimpan } \\
\text { gan }\end{array}$} & \multicolumn{2}{|c|}{ Jumlah } \\
\hline & $\mathrm{F}$ & $\%$ & $f$ & $\%$ & $\mathrm{~F}$ & $\%$ & $\mathrm{~F}$ & $\%$ \\
\hline Authotarian & 0 & 0 & 1 & 3,125 & 2 & 6,25 & 3 & 9,375 \\
\hline Permisif & 0 & 0 & 0 & 0 & 0 & 0 & 0 & 0 \\
\hline Authoritatif & 22 & 68,75 & 5 & 15,625 & 2 & 6,25 & 29 & 90,625 \\
\hline Jumlah & 22 & 68,75 & 6 & 18,75 & 4 & 12,5 & 32 & 100 \\
\hline
\end{tabular}

\section{Diskusi}

Berdasarkan analisa data menggunakan chi square menunjukkan hasil $\chi^{2}$ hitung 10,421 dengan $\alpha 0,05$. Oleh karena itu $\chi^{2}$ hitung lebih besar dari $\chi^{2} \alpha(10,421$ $>5,991)$ maka dapat disimpulkan bahwa H0 ditolak dan $\mathrm{H} 1$ diterima yang artinya pola asuh orang tua berhubungan dengan perkembangan emosional anak prasekolah usia 4-5 tahun di TK Kartika Jaya Kecamatan Kademangan, Kabupaten Blitar.

Menurut Yusuf (2012), hubungan pola asuh orang tua dimaknai sebagai proses pengalaman berinteraksi dan berkomunikasi dengan lingkungan keluarga, terutama dengan tua yang mengajar, melatih dan memberikan contoh berbahasa kepada anak.

Orang tua memiliki peranan yang sangat penting dalam upaya mendukung perkembangan anak, khususnya saat mereka berada pada tahapan usia dini. Namun permasalahan sering kali muncul, manakala orang tua sering kurang memahami teori perkembangan anak. Tidak adanya pendidikan khusus untuk mempersiapkan seseorang menjadi orang tua juga semakin mempersulit tugas orang tua dalam menangani berbagai permasalahan perkembangan anak. Pendidikan dan pengalaman orang tua dalam perawatan anak akan mempengaruhi persiapannya dalam menjalankan pengasuhan. Banyak cara yang dapat dilakukan untuk menjalankan peran pengasuhan, antara lain terlibat aktif dalam setiap pendidikan anak, mengamati segala sesuatu dengan berorientasi pada masalah anak, selalu berupaya menyediakan waktu untuk anak dan menilai perkembangan fungsi keluarga dan kepercayaan anak. Sebagian besar waktu kehidupan anak dilalui bersama dengan orang tua (misalnya ibu kandung) terutama pada ibu yang tidak bekerja di luar rumah. Namun untuk masyarakat kota-kota besar, dimana seorang ibu 
berperan ganda yakni juga bekerja diluar rumah, maka anak hidup bersama dengan kakek nenek atau pembantu rumah tangga. Hal itu seringkali menghadapi masalah, terutama berkaitan dengan perkembangan diri anak-anak..

Kegagalan dalam pola asuh yang diterapkan oleh orang tua yang kurang baik maka akan berdampak lebih lanjut akan mengakibatkan penyesuaian pribadi dan sosial yang buruk, membentuk konsep diri yang tidak menyenangkan, dan melemahkan kepercayaan pada diri sendiri. Bila penyimpangan mental emosional terlambat diketahui maka intervensinya akan lebih sulit dan hal ini akan berpengaruh pada tumbuh kembang anak. Deteksi ini dilakukan oleh tenaga kesehatan. Jika terjadi gangguan perkembangan, apapun bentuknya, deteksi yang dilakukan sedini mungkin merupakan kunci penting keberhasilan program intervensi atau koreksi atas gangguan yang terjadi. Semakin dalam

\section{DAFTAR PUSTAKA}

Daryo, Agoes.(2007). Psikologi Perkembangan Anak Tiga Tahun Pertama. Bandung: Refika Aditama

Depdiknas RI, (2005). Peraturan Menteri Pendidikan Nasional No.58 Tentang Standart Pendidikan Anak Usia Dini. Jakarta: Depdiknas R.I

Hasan, Maimunah. (2010). Paud ( Pendidikan Anak Usia Dini ). Yogyakarta: Diva Press

Hidayat, Aziz Alimul. (2011). Metode Penelitian Kebidanan dan Tehnik Analisa Data. Jakarta: Salemba Medika

Hidayat, DedeRahmat. (2009). Ilmu Pengantar Psikologi Untuk Tenaga Kesehatan. Jakarta : Trans Info Medika

Nursalam.(2005). Pertumbuhan Dan Perkembangan Anak. Jakarta: Salemba Medika

Patmonodewo, Soemiarti.(2008). Pendidikan Anak Prasekolah. Jakarta: RinekaCipta gangguan perkembangan terdeteksi, semakin tinggi pula kemungkinan tercapainya tujuan intervensi. Untuk mencapai tujuan tersebut, maka sejak awal keadaan pertumbuhan dan perkembangan harus dipantau, sehingga bila ada gangguan atau penyimpangan dapat segera ditangani dengan benar.

Dari penelitian yang telah dilakukan di TK Kartika Jaya Hasil penelitian menunjukkan bahwa ada hubungan antara pola asuh orang tua dengan penyimpangan mental emosional anak pra sekolah usia 4-5 tahun.

\section{Simpulan}

Berdasarkan hasil penelitian dan analisa data yang dilakukan maka dapat ditarik kesimpulan ada hubungan antara pola asuh orang tua dengan penyimpangan mental emosional anak prasekolah usia 4-5 tahundi TK Kartika Jaya Kecamatan Kademangan, Kabupaten Blitar.
Soetjiningsih, (2014).Tumbuh KembangA... Ir Jakarta: EGC

Septiari, Bety Bea.(2012). Mencetak Baııta Cerdas dan Pola Asuh Orang Tua. Yogyakarta : Nuha Medika

Tandry, Novita (2011). Mengenal Tahap Tumbuh Kembang Anak Dan Masalahnya. Jakarta : Libri

Yusuf, Syamsu.(2012). Psikologi Perkembangan Anak dan Remaja. Bandung : PT Remaja Rosdakarya

Ilham, (2013). Angka Kejadian Gangguan Emosional Anak Prasekolah. [Available fromhttp: //old.f k.ub.ac. $\underline{\mathrm{id} / \text { artikel } / \mathrm{id} / \text { filedownload }}$ \begin{tabular}{ll}
\hline keperawatan/ilham\% & 2 \\
\hline
\end{tabular} 0akbar 0910723004. pdf ]. AccesedOnApril5 ${ }^{\text {th }}$

Pricilla (2012). Angka Kejadian Gangguan Deteksi Dini Perkembangan. [Available fromhttp://cyntiapuspa.blogspot.com/20 
Soemarmi Sudjud; Hubungan Pola Asuh Orang Tua Dengan Penyimpangan Mental Emosional Anak Prasekolah Usia 4-5 Tahun

13/09/gangguan-emosional-onsetanak.html].AccesedOnApril $12^{\text {th }}$ Wekipedia (2014). Pengertian Orang Tua. [Available (http://id.shvoong.com/socialsciences/sociology/2336497pengertian-orangtua/html].Accesed OnApril $14^{\text {th }}$ at 20:28 